\title{
PENGARUH SENAM BUGAR LANJUT USIA TERHADAP KADAR KOLESTEROL
}

\author{
${ }^{1}$ Li Ping Pontoh \\ ${ }^{2}$ Damajanty H. C. Pangemanan \\ ${ }^{2}$ Herlina I. S. Wungouw
}

\author{
${ }^{1}$ Kandidat Skripsi Bagian Fisiologi Fakultas Kedokteran Universitas Sam Ratulangi Manado \\ ${ }^{2}$ Bagian Fisiologi Fakultas Kedokteran Universitas Sam Ratulangi Manado \\ Email: pingping_foreverfriends@yahoo.com
}

\begin{abstract}
Risks of coronary heart diseases (CHD), degenerative diseases, and metabolic disorders have increased in the elderly. Exercise and physical activity are beneficial to improve their physical fitness which can prevent or delay the occurences of the diseases. This study aimed to determine the effect of aerobic exercise for the eldery on blood cholesterol levels. This was a field experimental study with one group pre-post test design. Subjects were elderly who lived in BPLU Senja Cerah Manado. Blood cholesterol examinations were carried out before and after excercise. Thirty elderly were treated with elderly aerobic exercise routinely 3 times weekly for 3 consecutive weeks. Data were analyzed by using paired sample t-tests. The results showed that the mean cholesterol levels of the elderly before the designated exercise was $236.23 \mathrm{mg} / \mathrm{dL}$ and after the excercise was 195.63 $\mathrm{mg} / \mathrm{dL}$. Conclusion: The elderly aerobic exercises reduced blood cholesterol levels of the elderly.
\end{abstract}

Keywords: elderly, exercise, cholesterol, elderly aerobic exercise.

\begin{abstract}
Abstrak: Pada lanjut usia (lansia) terdapat peningkatan risiko penyakit jantung koroner (PJK), berbagai penyakit degeneratif, serta gangguan metabolisme. Kebugaran jasmani lansia sangat dibutuhkan untuk mencegah atau menunda perlangsungan penyakit-penyakit tersebut. Olahraga dan aktifitas fisik merupakan salah satu solusi untuk meningkatkan kebugaran jasmani. Penelitian ini bertujuan untuk mengetahui pengaruh senam bugar lansia terhadap kadar kolesterol darah. Penelitian ini bersifat eksperimental lapangan dengan rancangan pre-post one group test. Subyek penelitian ialah lansia yang berdiam di BPLU Senja Cerah Manado. Pengambilan darah dilakukan sebelum dan sesudah diberikan perlakuan. Subyek penelitian sejumlah 30 orang lansia yang diberi perlakuan berupa senam bugar lansia secara rutin 3 kali seminggu selama 3 minggu. Analisis statistik menggunakan paired sample t-test untuk menentukan pengaruh senam bugar lansia terhadap kadar kolesterol sebelum dan sesudah perlakuan dengan $\alpha=0,05$. Hasil penelitian menunjukkan bahwa rerata kadar kolesterol sebelum senam bugar lansia 236,23 mg/dL sedangkan sesudah senam bugar lansia selama 3 minggu 195,63 mg/dL. Simpulan: Senam bugar lansia yang dilakukan secara teratur dapat menurunkan kadar kolesterol darah pada lansia.
\end{abstract}

Kata kunci: lansia, olahraga, kolesterol, senam bugar lansia.

Risiko Penyakit Jantung Koroner (PJK), berbagai penyakit degeneratif, serta gangguan metabolisme akan meningkat pada lanjut usia (lansia). Salah satu penyebab berbagai penyakit tersebut ialah peningkatan kadar kolesterol dalam darah. ${ }^{1}$ Kebugaran jasmani sangat diperlukan untuk mencegah atau menunda perlangsungan penyakitpenyakit degeneratif dan gangguan metabolisme. Penyakit degeneratif ialah penyakit yang muncul akibat proses penuaan, sedangkan penyakit karena gangguan metabolisme ialah penyakit yang berhubungan dengan proses pembuatan 
energi, seperti diabetes melitus dan dislipidemia. $^{2}$

Kadar kolesterol total meningkat secara bertahap seiring bertambahnya usia. Peningkatan kadar kolesterol LDL dan rendahnya kadar kolesterol HDL merupakan prediktor penting untuk PJK baik pada laki-laki maupun perempuan yang berusia di atas 65 tahun. Pada lansia dengan PJK, peningkatan kolesterol meningkatkan risiko terjadinya kembali infark miokardium atau kematian. ${ }^{1,3}$

Usia berhubungan dengan perubahan metabolisme lipoprotein. Kadar kolesterol total meningkat pada laki-laki setelah pubertas sampai 50 tahun, berlanjut sampai 70 tahun, kemudian konsentrasi serum kolesterol sedikit menurun. Salah satu faktor penting yang memengaruhi kolesterol ialah perubahan berat badan. ${ }^{1}$

Olahraga bermanfaat untuk kesehatan jasmani maupun rohani. Manfaat olahraga di antaranya melancarkan sirkulasi darah, memperkuat otot, mencegah pengeroposan tulang, menurunkan tekanan darah, menurunkan kolesterol low density lipoprotein (LDL), dan menaikkan kolesterol high density lipoprotein (HDL). Olahraga juga bermanfaat untuk membakar kalori, meningkatkan keseimbangan dan koordinasi otot, meningkatkan kekebalan tubuh, menghilangkan sembelit, membuat tidur lebih nyenyak, serta mengurangi depresi. ${ }^{4}$

Bila para lansia ingin berolahraga, mereka harus memilih olah raga yang sesuai dengan kelompok usianya, serta mempertimbangkan adanya penyakit penyerta. Terdapat berbagai patokan olahraga untuk lansia yaitu antara lain beban ringan atau sedang, waktu relatif lama, bersifat aerobik dan atau kalistenik, serta tidak kompetitif/bertanding. ${ }^{5}$

Salah satu jenis olahraga yang bisa dilakukan oleh lansia yaitu senam bugar lansia. Aktivitas olahraga ini akan membantu tubuh tetap bugar dan segar karena melatih tulang tetap kuat, mendorong jantung bekerja optimal, dan membantu menghilangkan radikal bebas yang terdapat di dalam tubuh. Disamping memiliki dampak positif terhadap peningkatan fungsi organ tubuh, senam lansia juga meningkatkan imunitas dalam tubuh manusia setelah latihan teratur. ${ }^{6}$

\section{METODE PENELITIAN}

Penelitian bersifat eksperimental lapangan dengan rancangan pre-post one group test. Penelitian dilaksanakan pada bulan November-Desember 2012 dengan lokasi penelitian di Balai Panyantunan Lanjut Usia (BPLU) Senja Cerah Manado, Jln. M. W. Maramis No. 33 Paniki Bawah Manado 99256. Subjek penelitian ialah lansia yang berdiam di Badan Penyantunan Lanjut Usia (BPLU) Senja Cerah Manado dengan kriteria berusia $\leq 60$ tahun, sehat saat diperiksa, bersedia menjadi responden, dapat mengikuti senam bugar lansia, dan tidak memiliki riwayat stroke. Sebelum pengambilan darah dilakukan, subjek mengisi informed concent dan kuisioner untuk mengetahui kelayakan subjek penelitian. Pengambilan darah dilakukan sebelum dan sesudah diberikan perlakuan. Subjek berjumlah 30 orang dan diberikan perlakuan berupa senam bugar lansia selama 30 menit secara rutin 3 kali seminggu selama 3 minggu berturut-turut. Pemeriksaan darah dilakukan di laboratorium untuk menentukan kadar kolesterol subjek. Hasil penelitian diuji dengan paired sample t-test yang digunakan untuk menentukan pengaruh senam bugar lansia terhadap kadar kolesterol, sebelum dan sesudah perlakuan dengan $\alpha=0,05$.

\section{HASIL PENELITIAN DAN BAHASAN}

Senam bugar lansia dilakukan dengan iringan lagu dari $C D$ player. Pengambilan data dilaksanakan sebelum dan sesudah senam bugar lansia. Sebelum dilaksanakan penelitian, setiap subyek wajib untuk puasa selama 12 jam. Subjek penelitian yang berjumlah 30 orang terdiri dari 10 laki-laki dan 20 perempuan.

Penjaringan yang dilakukan berdasarkan pengisian kuisioner sebelum penelitian yang meliputi adanya riwayat stroke, nyeri dada saat melakukan aktivitas fisik, serta 
gangguan pada tulang atau persendian yang berat bila mengubah aktivitas fisik yang biasa dilakukan. Jumlah subyek laki-laki terbanyak pada usia 60-70 tahun, sedangkan jumlah perempuan terbanyak pada usia 71-80 tahun (Tabel 1).

Tabel 1. Distribusi subjek menurut usia dan jenis kelamin.

\begin{tabular}{|c|c|c|c|c|}
\hline \multirow{3}{*}{$\begin{array}{r}\text { Usia } \\
\text { (thn) }\end{array}$} & \multicolumn{4}{|c|}{ Jenis Kelamin } \\
\hline & \multicolumn{2}{|c|}{ Laki-laki } & \multicolumn{2}{|c|}{ Perempuan } \\
\hline & $\mathbf{n}$ & $\%$ & $\mathbf{n}$ & $\%$ \\
\hline $60-70$ & 6 & 20 & 8 & 26,7 \\
\hline $71-80$ & 1 & 3,3 & 9 & 30 \\
\hline \multirow{2}{*}{$81-85$} & 3 & 10 & 3 & 10 \\
\hline & 10 & 33,3 & 20 & 66,7 \\
\hline
\end{tabular}

\section{Kadar kolesterol pada kelompok sebelum dan sesudah melakukan senam bugar lansia}

Hasil analisis statistik menunjukkan kadar rerata kolesterol darah sebelum melakukan senam bugar lansia 236,23 $\mathrm{mg} / \mathrm{dL}$, sedangkan kadar rerata kolesterol sesudah melakukan senam bugar lansia 195,63 mg/dL (Gambar 1).

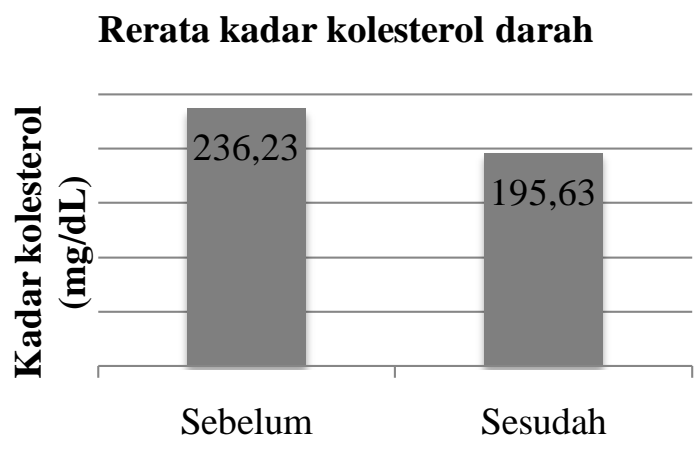

Gambar 1. Hasil pengukuran kadar kolesterol darah $(\mathrm{mg} / \mathrm{dL})$ subyek penelitian sebelum dan sesudah senam bugar lansia.

Pada kategori normal sebelum perlakuan didapatkan 5 orang dan sesudah perlakuan meningkat menjadi 15 orang. Pada kategori batas tinggi sebelum perlakuan didapatkan 14 orang dan sesudah perlakuan berkurang menjadi 10 orang. Pada kategori tinggi sebelum perlakuan didapatkan 11 orang dan sesudah perlakuan berkurang menjadi 5 orang (Gambar 2).

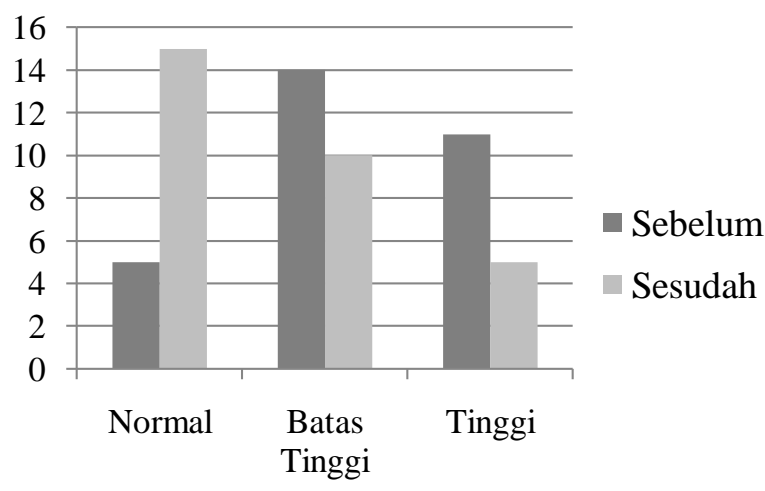

Gambar 2. Perbandingan kadar kolesterol darah sebelum dan sesudah senam bugar lansia dengan berdasarkan kategori normal, batas tinggi, dan tinggi

Pada penelitian ini, subjek berusia 6085 tahun terdiri dari 10 orang laki-laki dan 20 orang perempuan (Tabel 1). Pada usia 60-85 tahun, metabolisme lipoprotein dalam tubuh manusia mengalami perubahan yang mengakibatkan terjadinya peningkatan kadar kolesterol darah yang meningkatkan risiko terhadap kesehatan tubuh. ${ }^{1,4}$

Jumlah lansia dengan kadar kolesterol kategori normal sebelum dilakukan senam bugar lansia mengalami peningkatan setelah melakukan senam selama 3 minggu berturut-turut. Jumlah lansia dengan kadar kolesterol kategori batas tinggi dan kategori tinggi sebelum senam bugar lansia juga mengalami penurunan (Gambar 2). Hal ini menunjukkan bahwa senam bugar lansia dapat menurunkan kadar kolesterol darah.

Pada penelitian ini digunakan uji $t$ berpasangan untuk mengolah data hasil penelitian kadar koletserol dalam darah sebelum dan sesudah melakukan senam bugar lansia. Dari hasil data yang diperoleh ditemukan bahwa terdapat perbedaan bermakna (sig 2-tailed $=0,000<\alpha=0,05$ ) antara kadar kolesterol darah sebelum $(236,23 \mathrm{mg} / \mathrm{dL})$ dan sesudah $(195,63$ $\mathrm{mg} / \mathrm{dL}$ ) melakukan senam bugar lansia. 
Utomo et al. ${ }^{7}$ meneliti tentang pengaruh senam aerobic low impact terhadap kadar kolesterol darah pada remaja putri yang obes di sanggar senam Studio 88 Salatiga (2012) dengan jumlah subjek 10 orang. Senam aerobic low impact dilakukan 3 kali seminggu selama 2 bulan. Hasil penelitian diuji dengan uji $t$ berpasangan dan didapatkan hasil sig (2tailed) $=0,022<$ dari $\alpha=0,05$, yang menunjukkan adanya pengaruh latihan senam aerobik terhadap kadar kolesterol pada remaja putri obes. Penelitian Thristyaningsih et al. ${ }^{8}$ mengemukakan bahwa senam bugar lansia berpengaruh terhadap daya tahan jantung paru, status gizi dan tekanan darah, tetapi tidak dipaparkan pengaruh senam tersebut terhadap kadar kolesterol darah. Yang menjadi subjek pada penelitian tersebut ialah lansia di posyandu Kecamatan Pahandut Kota Palangka Raya sebanyak 74 orang. Fatimah dan Kartini $^{9}$ juga melakukan penelitian tentang senam aerobik dan konsumsi zat gizi serta pengaruhnya terhadap kadar kolesterol total darah pada perempuan. Pada penelitian tersebut, senam aerobik dilakukan 3 kali per minggu selama 6 bulan. Subjek penelitian ialah peserta senam aerobik di sanggar senam ST. Anna yang berjumlah 42 orang. Hasil uji statistik independent $t$ test menunjukkan tidak terdapat perbedaan bermakna $(P=0,401)$ antara kadar kolesterol total darah kelompok IRT (Ibu Rumah Tangga) dibandingkan kelompok peserta aerobik. ${ }^{9}$ Hatini dan Mulyanti ${ }^{10}$ melakukan penelitian tentang pengaruh senam lansia terhadap kadar kolesterol pada lansia yang merokok. Senam lansia dilakukan 3 kali per minggu selama 1 bulan secara rutin. Subjek penelitian ialah lansia yang merokok di Dusun Pirak Mertosutan Sidoluhur Godean Sleman Yogyakarta sebanyak 7 orang. Berdasarkan uji statistik didapatkan asymp. Sig. (2-tailed) $=0,000<$ $\alpha(0,005)$, sehingga dapat disimpulkan senam lansia yang dilakukan secara rutin efektif menurunkan kadar kolesterol darah pada lansia perokok. ${ }^{10}$ Penelitian-penelitian tersebut menyokong bahwa senam bugar (olahraga) rutin berpengaruh menurunkan kadar kolesterol pada berbagai jenis populasi.

Nilawati dan Krisnatuti ${ }^{11}$ menyatakan bahwa berolahraga secara teratur akan meningkatkan aktivitas berbagai enzim yang bertanggung jawab terhadap oksidasi lemak sehingga lebih banyak lemak yang digunakan sebagai sumber energi (pembakaran lemak dan kolesterol). Senam secara rutin akan menggunakan energi yang didapat dari cadangan karbohidrat dan lemak tubuh sehingga jumlah lemak bebas di dalam tubuh akan berkurang. Pendapat ini diperkuat oleh Soeharto ${ }^{12}$ yang menyatakan bahwa olahraga memecah timbunan trigliserida dan melepaskan asam lemak (dinamakan juga asam lemak bebas) dan gliserol ke dalam darah. Asam lemak bebas ini menjadi amat penting sebagai sumber bahan bakar bagi otot-otot, terutama bila latihan dikerjakan cukup lama. Bila latihan terus dilanjutkan, penggunaan asam lemak bebas oleh jaringan otot akan meningkat. Setelah 40 menit latihan, asam lemak bebas memasok $40 \%$ dari bahan bakar yang diperlukan. Latihan antara 1-2 jam dapat meningkatkan pasokan asam lemak bebas menjadi $\pm 65 \%$ sedangkan sisanya dipasok oleh glukosa. Seseorang yang terlatih dapat mengerjakan latihan berintensitas yang sama dengan menggunakan jumlah oksigen yang lebih sedikit, jumlah gula darah yang lebih sedikit, tetapi lebih banyak menggunakan asam lemak bebas (50-85\% dari energi yang digunakan). Oleh karena itu, olahraga dapat menurunkan kadar gula dan kolesterol dalam darah bila dilakukan lebih dari 30-60 menit dengan intensitas cukup. ${ }^{12}$

\section{SIMPULAN}

Berdasarkan hasil penelitian dapat disimpulkan bahwa senam bugar lansia yang dilakukan selama 30 menit tiga kali seminggu setelah tiga minggu berturutturut dapat menurunkan kadar kolesterol darah secara bermakna. 


\section{UCAPAN TERIMA KASIH}

Ucapan terima kasih ditujukan kepada dr. Hedison Polii, M.Kes, AIFM, AIFO, Dr. Joice N. A. Engka, MKes, AIFM, AIFO selaku penguji Skripsi dan semua pihak yang secara langsung maupun tidak langsung telah menumbuhkan ide dan gagasan pada penulis.

\section{DAFTAR PUSTAKA}

1. Ducharme N, Radhamma R. Hyperlipidemia in the eldery. Clin Geriatr Med. 2008;24:471-87.

2. Pranataha SB, Suharjana, Warsito AA. Pelatihan instruktur senam lansia bugar di Desa Wirirejo Pandak. Yogyakarta: Universitas Negeri Yogyakarta; 2012. p. 1-15.

3. Ganong WF. Keseimbangan energi, metabolisme dan nutrisi. In: Novrianti A, Dany F, Resmisari T, Rachman LY, Muttaqin $\mathrm{H}$, Nugroho $\mathrm{AW}$, et al, editors. Buku Ajar Fisiologi Kedokteran (Edisi 22). Jakarta: EGC, 2008; p. 320-1.

4. Rahayu TW. Proses penuan dan olahraga. Phedheral. 2010;3(2):37-45.

5. Bandiyah S. Lanjut Usia dan Keperawatan Gerontik. Yogyakarta: Muha Medika; 2009. p. 75.

6. Sumedi T, Wahyudi, Kuswati A. Pengaruh senam lansia terhadap penurunan skala insomnia pada lansia di panti werdha
Dewanata Cilacap. Jurnal Keperawatan Soedirman. 2010;5(1):13-20.

7. Utomo GT, Junaidi S, Rahayu S. Latihan senam aerobik untuk menurunkan berat badan, lemak dan kolesterol. Journal of Sport Sciences dan Fitness. 2012;1(1):6-10.

8. Thristyaningsih S, Probosuseno, Astuti H. Senam bugar lansia berpengaruh terhadap daya tahan jantung paru, status gizi dan tekanan darah. Jurnal Gizi Klinik Indonesia. Palangka Raya: 2011; 8. p. 14-22. Available from: http://jurnal.pdii.lipi.go.id/admin/jurnal /81111422_1693-900X.pdf

9. Fatimah S, Kartini A. Senam aerobik dan konsumsi zat gizi serta pengaruhnya terhadap kadar kolesterol total darah wanita. Jurnal Gizi Klinik Indonesia. 2011;8(1):23-7.

10. Hartini S, Mulyanti. Efektifitas senam lansia terhadap penurunan kadar kolesterol darah pada lansia merokok di Dusun Pirak Mertosutan Sidoluhur Godean Sleman Yogyakarta tahun 2009. Yogyakarta. p. 1-10. Available from: http://stikeskusumahusada.ac.id/ digilib/files/disk1/2/01-gdl-srihartini99-1-yanti,sr-2.pdf.

11. Nilawati S, Krisnatuti D. Care yourself, Kolesterol. Depok: Penebar Plus, 2008; p. 25 .

12. Soeharto I. Penyakit jantung koroner dan serangan jantung. Jakarta: Gramedia Pustaka Utama, 2004; p.409-11. 